\title{
Designing Practical Training System for EFL Learner Autonomy in View of Local Economic Development
}

\author{
Huanhuan Ren ${ }^{1, a}$, Chi Ma ${ }^{2, b}$ \\ ${ }^{1}$ Teaching and Research Institute of Foreign Languages, Bohai University, Jinzhou 121013, China; \\ ${ }^{2}$ Jinzhou Institute of Forestry Research, Jinzhou Forestry Bureau, Jinzhou 121013, China. \\ arenhuanhuan2014@163.com, 'bmachi2014@tom.com
}

Keywords: Practical training system, EFL learner autonomy, local economic development.

\begin{abstract}
The knowledge of a language is not only of academic value, but language in the wider sense also combines economic meanings. In designing practical training system for EFL learner autonomy, the principles of the issue of local economic development, and the synergy of language and economy should be considered and highlighted in view of local economic development. The major argument is that practical training system including curriculum-based practical training system, extracurriculum-based practical training system and post-based practical training system should be integrated into EFL learning framework so as to enhance the development of EFL learner individuals and local economy at large.
\end{abstract}

\section{Introduction}

The knowledge of a language is not only of academic value, but language in the wider sense also integrates economic meanings. This article reports on a research project on designing practical training system for EFL (English as foreign language) learner autonomy in view of local economic development. It is supposed that practical training system considering local economic development can trigger more EFL learner autonomy. One key argument here is how to establish a framework on practical training system for EFL learner autonomy to foster the development of individuals and society in view of local economic development. This paper is a summary of this research work, which hopefully provids a useful reference for future autonomous learning among EFL learners.

\section{Overview of English as Foreign Language (EFL)}

The Term of Foreign Language. Languages are complex combinations of elegant principles and historical meanings, and foreign language (FL) is regarded as one of the central topics in cognitive science. FL has been at the forefront of the research agenda in the language learning field in recent years. It refers to the process by which a person learns a language not spoken in the native country of the person. Compared with second language (SL), FL learners have the difficult task of finding access to authentic learning situations and seeking English models for themselves, as FL is usually learned in environments where the language they learn is not the language of the community and the school. Gunderson found that SL and FL instructional approaches differ in significant ways, and as the number of SL students has increased in schools across some regions, more classrooms and school have become more like FL than SL environments[1]. In sum, many theories about the learning and teaching of FL have been proposed from a various perspective, and have been by and large influenced by developments in the fields of linguistics, psychology, anthropology, and sociology.

Elements in EFL Learning. English language is the most commonly spoken language in the world, and is the main vehicle by which we know about other people's thoughts. It's agreed that English language is not only the language of the media industry, the language of the Interne, the language of business, the language of science, but it's also the language of opportunities. There is a growing concern and interest in English as a foreign language (EFL) both at home and abroad. when EFL is researched among language scholars, two distinctive approaches come to the surface: 
acquisition or learning. There is an important distinction made by linguists between language acquisition and language learning. Language acquisition refers to the natural way of picking up a language by using it in natural, communicative situations. It's a subconscious process during which language is acquired similarly as children acquire their first language. Language learning, by contrast, is involving a conscious knowledge about grammar and conscious rules about a language. In this context, EFL learning should be targeted toward a more communicative learning approach, so that the effects of language learning can be enhanced in EFL learning process.

For Autonomy in EFL Learning. Learner autonomy has gained in popularity and has become one of the new EFL buzzwords since the 1980s, and learner autonomy has so far been a key theme in the field of EFL learning for over 30 years. A significant body of research about learner autonomy in EFL field has been carried out, however, there has been a debate on the definitions of learner autonomy in language learning with different perspectives and from various viewpoints. It's argued that autonomous learning is a process and not a product that many EFL students seek today[2]. According to Little, it requires language learners to make out a personal agenda for learning that sets up directions in the planning, pacing, monitoring, and evaluation of the learning process[3]. Also Benson claims that learner autonomy is a capacity for taking control of learning [4]. It's concluded from above that learner autonomy can be identified as a construct of complicated capacity for making informed decisions about one's own learning and taking control of one's own learning. In sum, learner autonomy ought to be considered as an important goal in EFL learning as it has gradually played a fundamental role in educational research and teaching practice.

\section{The Designing Principles of Practical Training System for EFL Learner Autonomy in View of Local Economic Development}

The Issue of Local Economic Development. The development of EFL learning should take local economic development into consideration. How are EFL learning related with local economic development? The explanation are denoted in two dimensions. On one hand, the concept of learner autonomy, particularly in foreign language learning, has been argued to be very complex as it's economically driven. Language is linked to local economic development, and is one important ingredients influencing the local economic growth. Language planning and language policies serve as tools to direct society in the economic sense. On the other, economic developments influence the emergence, expansion, or decline of languages[5]. People are more aware that it is due to local economic development that the number of available jobs and the number of jobs being created that require significant knowledge of English is on the rise. Proficiency in English, may provide an advantage for careers and employment in certain sectors of the local economy. In sum, economy in linguistics can have lots of different values and meanings and can be considered and studied from diverse viewpoints.

The Synergy of Language and Economy. There are various approaches for considering the link between language and economy. In today's global society, more than in the past, the interaction between economy and language is a reality. The implications of the synergy of economy and language are profound. Contemporary foreign language teaching seeks for the proliferation of approaches, methods and theories so as to search for more efficient and effective ways of teaching languages. In other words, many students look for ways to improve their linguistic skills without having to make significant financial sacrifices. Moreover, when we look at language in its global role, the economic dimension is what determines its value and status in countries with aspirations to participate in the knowledge economy. Various economic factors have an impact on changes in the meaning of languages. In brief, language and economy interact as language has a specific value which is marked by the economic variables and economy in the widest meaning indirectly and directly influences various language processes. 


\section{A Framework on Practical Training System for EFL Learner Autonomy in View of Local Economic Development}

In order for EFL learners to enhance EFL learner autonomy, a framework of practical training system is needed in view of local economic development. The module covering at least three areas should be integrated in the framework on practical training system for EFL learner autonomy: curriculum-based practical training system, extracurriculum-based practical training system and post-based practical training system, as shown in Fig. 1.

A Curriculum-based PTS

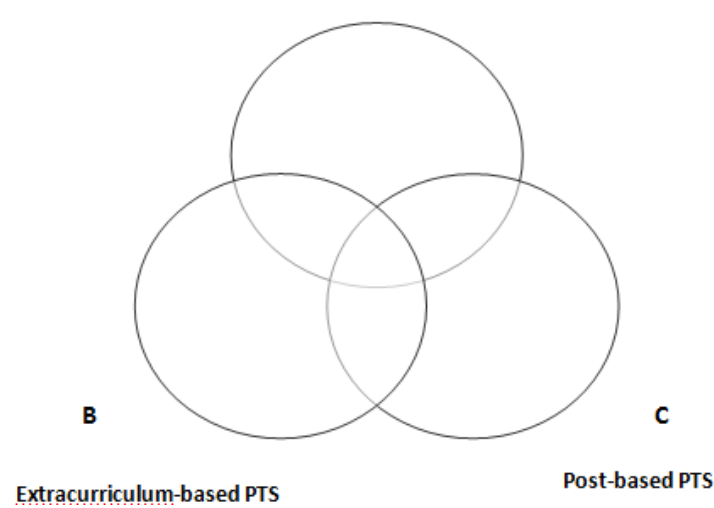

Fig. 1. Practical training system (PTS) for EFL learner autonomy

Curriculum-based Practical Training System for EFL Learner Autonomy. Developing learner autonomy in a classroom requires a gradual move. There is some truth in the idea that the development of learner autonomy is closely linked with good classroom management and lesson planning, and English instructors should be well prepared with various classroom activities before each class. With view to serving local economic development, the knowledge and skilled learned in classroom should be practical, be closed related to the real needs of the industry need. In other word, it's not simple the EGP learning, ESP learning should be designed into the framework, including business English, management English, tourism English, financial English, etc. Besides, learners who are in the process of classroom learning are anticipated to readily acquire the language to communicate with classmates because classroom is deemed a place for discussion and interaction as opposed to a place for simply transferring of knowledge. Moreover, freedom, choice, and negotiation are often identified as crucial environment factors for learner autonomy development. All in all, the incorporation of autonomy as a goal in the college English curricula in china has led to classroom-based approaches aiming at the development of learner autonomy and an ultimate actualization of an education towards autonomy.

Extracurricular-based Practical Training System for EFL Learner Autonomy. The link between learner autonomy and effective learning inevitably has led to various pedagogical attempts in widely varying contexts to foster learner autonomy. It's argued that extracurricular-based learning is highly needed by English language learners. The evidence is overwhelming that more work should be done outside classroom for it's not beneficial for knowledge construction, but also raise EFL learner autonomy. In this process, teachers are anticipated to teach learners how to learn and take a notice of their learning process, involving learning objective, learning method, learning contents, learning assessment. One more thing is that a rich wealth of resources should be open to all learners, and a large number of EFL learning centers are encouraged to establish for EFL learners with relevant materials updated accordingly. In most cases, skills can be learned by studying independently and with other EFL students, but more benefits of English learning in an informal classroom environment may accrue from obtaining help and suggestions from a qualified mentor through solving language difficulties in learning process. In sum, it is difficult to improve language skills exclusively through classroom learning, and learning can take place without having a teacher physically present with sufficient guidelines given to learners. 
Post-based Practical Training System for EFL Learner Autonomy. There are various reasons for the post-based learning, which targets for EFL learner autonomy through on-the-job experience. It's agreed that the knowledge and skills can be acquired through being applied by ELL learners in the practice and being regularly used in social context which helps explain what really goes on in the learning process. In other words, it is not sufficient to look only within the classroom to understand this interaction because much of what goes on within the classroom is influenced by factors within the wider educational institute, the wider educational environment and the wider society. Instructors are encouraged to establish close contact with society, and seek for more internship or part-time opportunities for EFL learners. More internship jobs can be posted for more chances of learning in society, so that learners can have access to the real society. It's good for EFL learners to find their weakness and strong points in language learning, and meanwhile enterprises can benefit more from employing those who perform well in the internship period because brain drain can be avoided in this regard. In sum, joint efforts should be made between English language learners and targeted corporations so that win-win objective can be achieved between them.

\section{Summary}

From above, it's found that the main emphasis in EFL leaner autonomy that matter for future local economic development would focus on the matter of designing practical training system for EFL learners in China. In designing practical training system for EFL learner autonomy, the principles of the issue of local economic development, and the synergy of language and economy should be considered and highlighted. The major argument of this thesis is that practical training system including curriculum-based practical training system, extracurriculum-based practical training system and post-based practical training system are ought to be integrated into EFL learning framework so as to enhance EFL learner autonomy in view of local economic development.

\section{Acknowledgement}

This work is part of the project of On Cultivating and Developing Liaoning Scientific Foreign Language Talents with View to Bourdieu' Theory, the project of On Establishing Generative Mechanism of EFL Autonomous Learning Behaviors and Strengthening Development of Learning Field in Ubiquitous Learning Space, and the project of On Constructing Mechanism and Strategies for College English Autonomous Learning Abilities via Mobile Multimedia. This research was supported by the fund of Liaoning Planning of Philosophy and Social Science (Project No. L16CYY001), the fund of Liaoning Provincial Federation Social Science Circles (Project No. 2017lslktyb-019), and the fund of the Thirteenth Five-Year Plan of Education Sciences of Liaoning Province (Project No. JG16DB013).

\section{References}

[1] G. Lee, ESL (ELL) Literacy Instruction: A Guidebook to Theory and Practice, 2nd ed. Routledge, 2009.

[2] A.G. P. Nowlan, Motivation and Learner Autonomy: Activities to Encourage Independent Study, The Internet TESL Journal, 2008 (10).

[3] D. Little, Learner autonomy: A theoretical construct and its practical application, Die Neuere Sprache, 1994, 93(5).

[4] P. Benson, Teaching and Researching Autonomy in Language Learning, Lonsdon: Longman, 2001

[5] F. Coulmas, Language and economy. Oxford: Blackwell Publishers, 1992. 